\title{
ALOKASI DANA KHUSUS (ADK) UNTUK MASA DEPAN PENDIDIKAN ANAK
}

\author{
Olenggius Jiran Dores, Ursula Dwi Oktaviani, Beni Setiawan, Frederykus Ege \\ STKIP Persada Khatulistiwa Sintang \\ olenggius@gmail.com,ursuladwioktaviani@yahoo.com, benisetiawan1892@gmail.com, \\ fredyege@yahoo.co
}

\begin{abstract}
Education now requires a high cost but the economy is not stable, the impasse many people who cannot afford to send their children to college because of family financial factors. For that we need training on "Allocation of Special Funds for the Future of Children's Education". This training is aimed at the head of the family or parents / children of school age, this is because the head of the family is more dominant in allocating family finances and decision makers. The general purpose of PkM is to provide training and description to the community / parents of students how to manage family finances for children's education. The methods used in this PkM are Counseling, Training and Guidance on; a) Benefits and Functions of Education for Children, b) How to Identify Family Income Resources, c) How to Identify Family Expenditures, and d) How to Strategy or Management / Financial Management for the Preparation of Child Education. Extension and Training activities will be held in October - December 2017 at the Village Office Senempak, South Pinoh District Melawi District.
\end{abstract}

Keywords: Special Fund Allocation, Senempak, Child Education

\begin{abstract}
Abstrak : Pendidikan saat ini memerlukan biaya yang tinggi tetapi perekonomian belum stabil, impasnya masyarakat banyak yang tidak mampu menyekolahkan anak-anak mereka sampai perguruan tinggi karena faktor keuangan keluarga. Untuk itu diperlukan suatu pelatihan mengenai "Alokasi Dana Khusus untuk Masa Depan Pendidikan anak". Pelatihan ini ditujukan untuk kepala keluarga atau orang tua siswa/anak usia sekolah, hal ini dikarena kepala keluarga yang lebih dominan dalam mengalokasikan keuangan keluarga serta pengambil keputusan. Tujuan Umum PkM ini adalah memberikan pelatihan dan gambaran kepada masyarakat/orang tua siswa bagaimana memanajemen keuangan keluarga untuk pendidikan anak. Metode yang digunakan dalam PkM ini yaitu Penyuluhan, Pelatihan dan Bimbingan tentang; a) Manfaat dan Fungsi Pendidikan Untuk Anak, b) Bagaimanan Mengidentifikasi Sumber-sumber Pendapatan Keluarga, c) Bagaimana Mengidentifikasi Pengeluaran Keluarga, dan d) Bagaimana Strategi atau Manajemen/Pengelolaan Keuangan untuk Persiapan Pendidikan Anak. Kegiatan Penyuluhan dan Pelatihan ini akan dilaksanakan pada bulan Oktober - Desember 2017 di Kantor Desa Senempak, Kecamatan Pinoh Selatan Kabupaten Melawi.
\end{abstract}

Kata Kunci: Alokasi Dana Khusus (ADK), Senempak, Pendidikan Anak 


\section{PENDAHULUAN}

Pendidikan adalah pembelajaran pengetahuan, keterampilan, dan kebiasaan sekelompok orang yang diturunkan dari satu generasi ke generasi berikutnya melalui pengajaran, pelatihan, atau penelitian. Secara umum pendidikan merupakan salah satu dari berbagai investasi manusia yang sangat memberi andil dalam peningkatan kualitas sumber daya manusia. Dengan pendidikan maka seorang individu akan dapat meningkatkan pengetahuan dan keterampilannya sehingga menjadi manusia yang memiliki sumber daya yang berkualitas sesuai harapan (Faturrahman, dkk. 2012). Dengan kualitas sumber daya manusia yang baik diharapkan manusia dapat membuka cakrawala berpikir, memperluas wawasan serta menguasai pemanfaatan ilmu pengetahuan dan teknologi yang nantinya dapat memberikan kontribusi yang besar dalam memajukan pembangunan nasional.

Salah satu penyebab utama dari pengangguran ialah faktor pendidikan yang kurang memadai, karena di jaman sekarang ini orang yang tidak memiliki pendidikan yang tinggi akan tergeser oleh orang-orang yang memiliki pendidikan yang lebih tinggi darinya (Hadis, 2006). Sedangkan kondisi pendidikan di
Indonesia belum bisa sampai pada tahap maksimal seperti pada Negara-negara maju yang memiliki kondisi pendidikan sudah pada tahap yang diinginkan. Pada hakekatnya pendidikan tidak bisa dilepaskan dari masalah ekonomi keluarga, dalam mengoptimalkan pendidikan ke jenjang lebih tinggi maka faktor ekonomi merupakan faktor yang sangat menentukan dalam kelanjutan pendidikan khususnya pendidikan anak (Hafid, dkk 2013). Untuk menjamin lancarkan proses pendidikan anak, keluarga memegang peranan penting, terutama dalam hal biaya pendidikan anak. Namun sering kali banyak orang tua memilih untuk tidak menyekolahkan anak dikarenakan mahalnya biaya pendidikan. Oleh karena itu pelatihan pendidikan keuangan perlu untuk diberikan kepada masyarakat karena adanya siklus pemasukan dan pengeluaran.

Di Desa Senempak Kecamatan Pinoh Selatan, Anak dari masyarakatnya banyak yang putus sekolah dan banyak yang tidak melanjutkan pendidikan kependidikan tinggi, berdasarkan observasi dan wawancara dengan masyarakat sekitar ditemukan penyebab utama anak putus sekolah dan tidak melanjutkan pendidikan ketingkat yang lebih tinggi diakibatkan faktor ekonomi 
keluarga. Penghasilan keluarga tidak mampu untuk menyekolahkan anak-anak mereka, apalagi pendidikan jaman sekarang sangat mahal. Penghasilan utama masyarakat yaitu petani karet dan membuka ladang untuk kebutuhan seharihari, Harga karet yang sampai saat ini belum stabil mengakibatkan keuangan keluarga juga sulit, dan ada juga pengaruh kebijakan pemerintah yang melarang masyarakat untuk membuka lahan untuk ladang dan membakar ladang membuat masyarakat semakin dilema dengan perekonomian keluarga.

Kesulitan keuangan merupakan alasan utama masyarakat. Hal ini dikarenakan masyarakat kurang memahami bagaimana mengelola keuangan dan kurangnya pengetahuan tentang memilah fungsi keuangan/memanajemen keuangan. Jika hal tersebut dibiarkan tentu akan sangat riskan bagi masa depan pendidikan anak. Mengatasi hal tersebut, perlu diberikan pendidikan keuangan keluarga. Untuk itu, judul pengabdian ini adalah pelatihan Alokasi Dana Khusus (ADK) Untuk Masa Depan Pendidikan Anak.

Adapun tujuan dari kegiatan PkM dalam bentuk penyuluhan dan pelatihan ini yaitu:
1. Memberi Pemahaman kepada Masyarakat/Orang tua tentang pentingnya pendidikan untuk Anak.

2. Memberikan Pelatihan bagaimanana mengidentifikasi sumber-sumber pendapatan keluarga.

3. Memberi Pelatihan bagaimanana mengatur pengeluaran keluarga.

4. Memberi Pelatihan bagaimanana mengalokasikan dana khusus untuk pendidikan anak.

Sedangkan yang menjadi target Luaran yang akan dihasilkan dalam kegiatan PkM ini yaitu sebagai berikut:

1. Jurnal catatan Sumber-sumber Pendapatan keluarga; Masyarakat dapat mengidentifikasi sumber-sumber pendapatan sehari-hari dan meningkatkan sumber-sumber pendapatan keluarga.

2. Jurnal catatan Pengeluaran Keluarga; Masyarakat dapat mengidentifikasi pengeluaran keluarga dan mengelola keuangan keluarga.

3. Tabungan Khusus untuk Pendidikan anak; Masyarakat dapat menyisihkan dana khusus untuk pendidikan anak dari pendapatan keluarga yang kemudian ditabung 


\section{METODE PELAKSANAAN}

Metode pelaksanaan dalam kegiatan PkM ini yaitu dalam bentuk Penyuluhan dan Pelatihan, adapun tahap atau langkahlangkah kegiatan yaitu sebagai berikut:

1. Peserta diberi materi tentang pentingnya pendidikan untuk anak.

2. Peserta diberi materi tentang mengidentifikasi sumber-sumber pendapatan dan pengeluaran keluarga.

3. Masing - masing peserta diberi jurnal untuk mencatat sumber - sumber pendapatan dan pengeluaran keluarga.

4. Peserta

dibimbing

untuk mengidentifikasi sumber-sumber pendapatan keluarga dengan mencatat pendapatan keluarga.

5. Peserta dibimbing untuk mengidentifikasi pengeluaran keluarga dengan mencatat pengeluaran pengeluaran keluarga baik individu maupun untuk kebutuhan keluarga.

6. Peserta diminta untuk mengurangi pengeluaran - pengeluaran yang kurang bermanfaat.

7. Peserta dibimbing bagaimana menyisihkan penghasilan keluarga untuk ditabungan sebagai pesiapan untuk pendidikan anak.

8. Peserta diarahkan untuk membuka tabungan khusus untuk pendidikan anak (di Koperasi, Credit Union (CU) dan BANK ).

\section{HASIL DAN PEMBAHASAN}

Kegiatan PkM dalam bentuk Penyuluhan dan Pelatihan yang berjudul "Alokasi Dana Khusus (ADK) Untuk Masa Depan Pendidikan Anak" telah dilaksanakan dengan cara memberikan penyuluhan langsung melalui tatap muka/praktek. Kegiatan tersebut dilaksanakan selama satu hari yakni pada hari Jumat 10 November 2017, bertempak di kantor Desa Senempak. Kegiatan ini diikuti oleh 48 orang masyarakat (presensi terlampir). Dalam kegiatan tersebut masyarakat terlihat antusias dalam mengikutinya mulai dari awal hingga akhir kegiatan. Kegiatan tersebut berjalan dengan baik, sesuai dengan yang direncanakan.

Adapun rangkaian kegiatan $\mathrm{PkM}$ yang telah dilaksanakan adalah sebagai berikut:

1. Pembukaan oleh MC Bpk. Beni Setiawan., M.Pd

2. Menyanyikan Lagu "Indonesia Raya"

3. Kata Sambutan Ketua PkM oleh Bpk. Olenggius Jiran Dores., M.Pd

4. Kata Sambutan Kepala Desa Senempak Bpk. Sahidin, Sekaligus Membuka secara Resmi Kegiatan PkM

5. Doa (Bpk. Malgono., S.Pd.I)

6. Penyampaian materi 1 yakni "Pentingnya Pendidikan untuk Anak" oleh Bpk. Olenggius Jiran Dores., M.Pd

7. Penyampaian materi 2 yakni "Mengidentifikasi sumber-sumber Dores, dkk, Alokasi Dana...79. 
pendapatan dan pengeluaran keluarga"

Oleh Ibu Ursula Dwi Oktaviani, M.Pd

8. Penyampaian materi 3 yakni "Menambah Penghasilan Keluarga dan Menyisihkan Penghasilan Keluarga untuk masa depan Pendidikan Anak" oleh Bpk. Frederykus Ege., M.Pd

9. Sesi tanya jawab dipandu oleh MC

Penutup

Adapun hasil dokumentasi kegiatan yang telah dilakukan yaitu sebagai berikut:

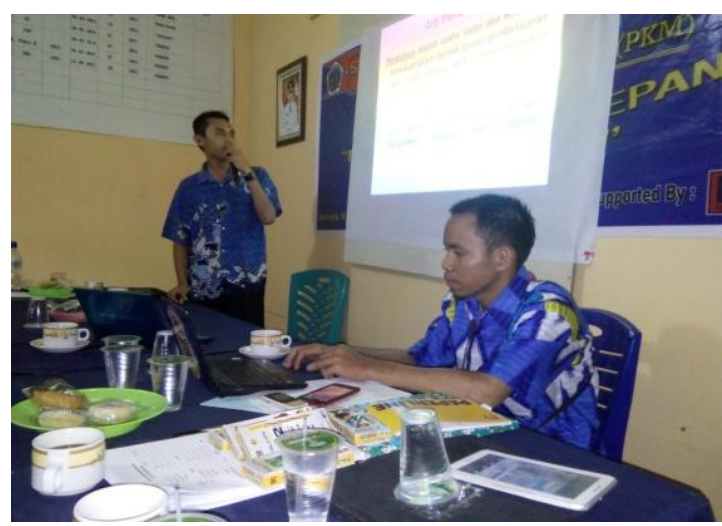

Gambar 1. Menyajikan Materi

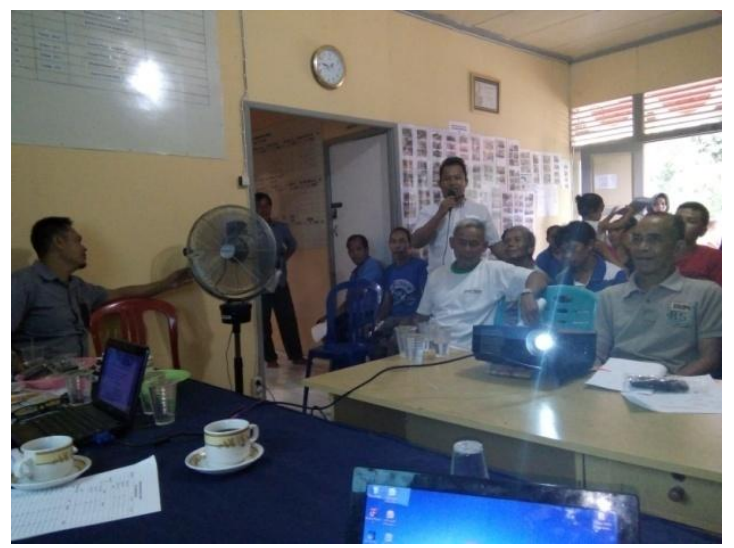

Volume 1 Nomor 2 Nopember 2018

\section{Gambar 2. Tanya Jawab}

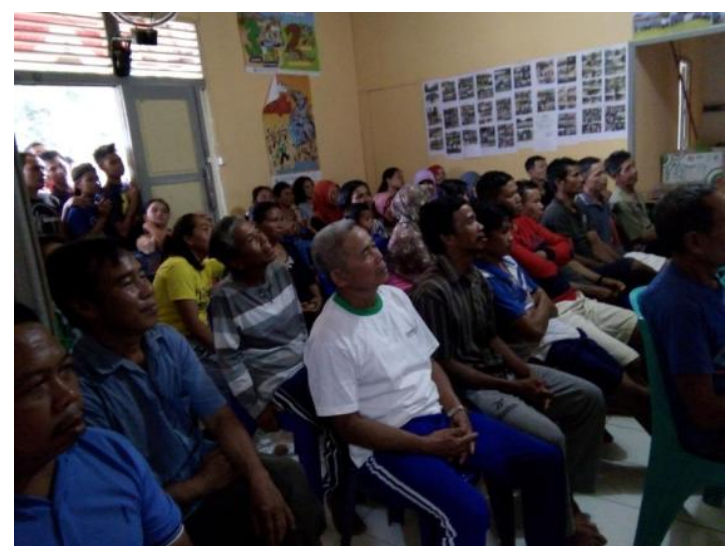

Gambar 3. Para Peserta Menyimak Materi

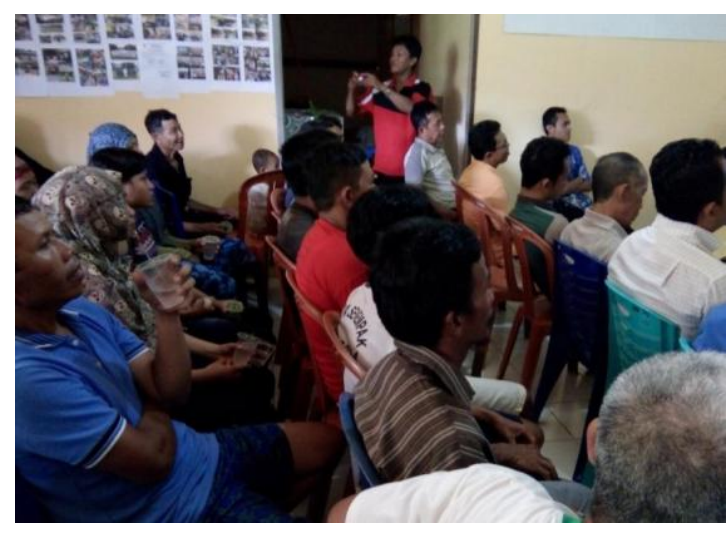

Gambar 4. Peserta Praktik (Pelatihan)

Kegiatan berjalan dengan baik dan lancar sesuai dengan yang sudah direncanakan dan dapat dukungan yang baik dari perangkat desa dan masyarakat setempat. Masyarakat tampak antusias dalam mengikuti pendidikan melalui pelatihan. Antusiasme warga terlihat dari keseriusan mereka dalam menyimak, aktif dalam diskusi/tanya jawab maupun praktek menghitung pendapatan dan pengeluaran masing - masing. Keingin tahuan mereka ini tentunya dikarena

Dores, dkk, Alokasi Dana...80. 
melaui pendidikan seorang individu akan dapat meningkatkan pengetahuan dan keterampilannya

(Faturrahman, dkk. 2012). Selain itu jugan, ekonomi merupakan faktor yang sangat menentukan dalam kelanjutan pendidikan khususnya pendidikan anak (Hafid, dkk 2013)

\section{SIMPULAN}

Kegiatan PkM dalam bentuk Penyuluhan dan Pelatihan yang berjudul "Alokasi Dana Khusus (ADK) Untuk Masa Depan Pendidikan Anak" telah berjalan dengan baik dan lancar sesuai dengan rencana kegiatan yang telah disusun. Kegiatan ini mendapat sambutan dan dukungan yang sangat baik dari masyarakat, mengingat di desa tersebut terdapat banyak anak - anak yang putus sekolah. Faktor utama penyebabnya adalah biaya. Oleh karenanya kegiatan ini mendapat banyak perhatian dari masyarakat, hal ini terbukti dengan banyaknya peserta yang mengikuti yaitu 48 peserta. Selama kegiatan berlangsung para peserta pun antusias dan aktif dalam mengikuti kegiatan mulai dari awal hingga kegiatan berakhir.

\section{DAFTAR RUJUKAN}

Faturrahman, dkk. 2012. Pengantar Pendidikan. Jakarta:Prestasi Pustaka Publisher

Hadis, Abdul. 2006. Psikologi dalam Pendidikan. Bandung: Alfabeta

Hafid, Anwar, dkk. 2013. Konsep Dasar Ilmu Pendidikan. Bandung : Alfabeta

Leny Nofianti, Angrieta Denziana. 2010. Manajemen Keuangan Keluarga. Jurnal UIN Suska Riau (https://www.google.co.id/url?sa=t \&rct $=\mathrm{j} \& \mathrm{q}=\&$ esrc $=\mathrm{s} \&$ source $=\mathrm{web}$ $\underline{\mathrm{cd}=3 \& \mathrm{cad}=\mathrm{rja} \& u a c t=8 \& v e d=0 \mathrm{a}}$ hUKEwjEtJr63IrWAhWLpo8KH YwSBlwQFgg2MAI\&url=http\%3 A\%2F\%2Fejournal.uinsuska.ac.id\%2Findex.php\%2Fmar wah\%2Farticle\%2Fdownload\%2F 481\%2F461\&usg=AFQjCNHVV wUfZeWomCrF69zHd3sva-yUSQ diakses tgl 3 September 2017

Rodhiyah.2012. Manajemen Keuangan Keluarga Guna Menuju Keluarga Sejahtera. Jurnal (https://www.google.co.id/url?sa=t \&rct $=\mathrm{j} \& \mathrm{q}=\&$ esrc $=\mathrm{s} \&$ source $=$ web $\&$ $\underline{\mathrm{cd}=1 \& \mathrm{cad}=\mathrm{rja} \& u a c t=8 \& v e d=0 \mathrm{ahU}}$ KEwjEtJr63IrWAhWLpo8KHYwS BlwQFggrMAA\&url=http\%3A\%2F $\% 2 \mathrm{Fdownload}$.portalgaruda.org\%2F article.php\%3Farticle\%3D23009\%2 6val\%3D1295\&usg=AFQjCNEkVq 9vlXyavl_SX0gMn-9c0ZyjBQ) diakses tgl 3 September 2017 